\title{
The research of Born Global Firms' transnational strategy
}

\author{
Li Chong ${ }^{1, a}$ \\ ${ }^{1}$ Faculty of International Trade, Shanxi University of Finance and Economics, Wucheng Road 56, Taiyuan, China
}

\begin{abstract}
With the development of global business, Born Global Firms are always sinking into various pressures which are related to economic factors, social factors and informational factors. This situation making Born Global Firms' strategies is supposed to achieve those requirements that including global market integration, social responsiveness, worldwide learning. There are four important strategies which are widely used in Born Global Firms internationalization process that including multinational strategy, global strategy, international strategy, and transnational strategy. This essay will introduce pursuing transnational strategy and some difficulties existing in this process. Furthermore, an example of an entrepreneurial subsidiary will be chosen to explore and conduct further research.
\end{abstract}

\section{INTRODUCTION}

With the development of global economy, R\&D international strategy has been developed an essential way for most of the multinational enterprises to ask for significant profits in the short term and improve their competitiveness in a long time. R\&D international strategy will help MENS protect their local property and enhance the possibility for their foreign subsidiaries to make successful in the overseas market (Serape, 1997). In the business environment, the nature of R\&D strategies is to ask for high-quality and inexpensive resources (Ivo, 1999). The variety of resources decided on the various motivation to operate R\&D strategies. Furthermore, different countries' political, cultural and economic environments also make challenges to operating this internationalization strategy into another country. This essay will aim to investigate the main factors that influence their decision of outsourcing R\&D internationally. In addition, the challenges in the application and implementation of this strategy are assessed through both internal and external environments factors.

\section{THE RESEARCH ABOUT MOTIVATION OF R\&D}

\subsection{CHEAP LABOUR COST}

The International Labor Organization (ILO) has defined an $\mathrm{MNC}$ as a corporation that has its management headquarters in one country, known as the parent company. It operates in several other countries (Pavlos, 2016). One of the important reasons for those companies developing their subsidiaries in other countries is cheap labour. This phenomenon was widely witnessed by international traditional manufacturing and high-tech electronics industry downstream industry.

After the 1960s, developed countries such as America, Germany, and Japanese started to transfer their factories and technology into other developing countries by influenced technology innovation. In the year of 1970s, by the influence of energy crisis in the worldwide, developed countries improve their effective about industries and technology transfer (Tann, 2015). The aim of these strategies was reducing labour cost to enhance their profits and achieve industrial innovation. After the 1990s, with the Chinese policies changed and developed countries' technology innovation, China starts to become a worldwide factory. In fact, the demographic dividend has already become Chinese significant competitiveness advantages to taking part in an MNES R\&D network (Cai, 2010).

By the research of ILO, Chinese manufacturing's labour cost is approximately 1 dollar per hour. However, in some developing countries such as Malaysia and Mexico, labour cost is twice than the Chinese. In developed countries such as America, Germany, Japanese, and Canada, labour cost is over than 15 dollars per hour (ILO, 2005). In the year of 2005, Chinese labour-intensive industries contribute $22.5 \%$ growth of Chinese GDP development. This contribution is over than other developed countries (Cai, 2010). However, this contribution is reduced by influenced by Chinese government improving basic labour wage. In the year of 2015, Chinese labour is up to almost 1.51 dollar per hour. Other Asian countries such as Thailand, Philippines, India, and Indonesia are $\$ 1.17, \$ 0.8, \$ 0.41$, and $\$ 0.35$ respectively. In the past few years, MENS' FDI into those countries is over than the Chinese market. Besides, the cheap labour offered in recent year has shown an increase of quality especially in China and India, this substantialquality increase has allowed this group of the labour force

aBourne_li@163.com 
to be acceptable for R\&D use (Sun et. al, 2013). Based on this data, it could be easily found that the relationship between labour cost and MNES' R\&D strategies. In fact, looking for cheap labour cost to reduce enterprises' running cost is an essential motivation for MNES operates their R\&D strategies into other countries.

\subsection{NATURAL RESOURCES}

Resource-oriented enterprises focus on using locally available resources to develop their business in the current market. There are some international companies are belong to resource-oriented, or they are treating those resource-oriented enterprises as their essential part of their business networks. One of the judgment standards about resource-oriented enterprises is that resource cost proportion to enterprises' total cost (Baranenko, 2014). Resource-oriented enterprises normally include energy import and export enterprise, low-end manufacturing products, and raw material processing industries.

Mittal Steel is a famous iron and steel enterprises worldwide. It is the creation by combine LNM Holdings and Ispat Steel Group in 2004. Before 2004, LNH Holding was the predecessor of Mittal Steel (Usa.arcelormittal.com, 2016). Mittal Steel uses CrossBorder Mergers and Acquisitions to achieve their development in the past decades years. In the year of 1992, LNH Holding used Cross-Border Mergers to control Mexican Sicartsa joint venture. This strategy helps LNH Holding master mining rights about Mexico iron ore resource which are located on the Pacific coast and along the northern highlands. In the year of 2004, Mittal Steel used over 400 million dollars to share Valin Group. They use this strategy to enjoy Chinese cheaper iron ore in the Asian market (Rogers, 2009).

In fact, with the mining technology development and the Steel market improvement, the cost of Iron ore mining is reducing, and the profits of Steel is increasing. Furthermore, get benefit from the development of technology; products transfer cost is also decreasing in the past few months. Steel manufacturing develops its subsidiaries are not just limited by the location of natural resources. The other factors such as transport cost, the need of the market, and national policies about environment protection are the trend to be considered by the owners of Steel manufactural. However, based on the research about Mittal Steel Cross-Border Mergers and Acquisitions behaviours, cheaper natural resources can improve the possibility of successful about those companies when they operate their business plan into other countries. With the available resourced offered in a foreign country, companies could develop and research new areas such as further technology testing or development of new material research showed above. Therefore, increasing the access to an external natural resource could be one of the motivations for the company to expand its available $R \& D$ into foreign countries.

\subsection{TECHNOLOGY}

Technology is defined as anything used by humans to shape their surrounding world (Stokes, 2016). Actually, technology is an essential motivator of developed countries' FDI into other developed countries. Kougut and Chang pointed out that American and European FDI is coming from the host country's R\&D spillover effect (Kougut\&Chang, 1991). In the year of 1996, Neven and Siotis did more research about that and proved this phenomenon also happened in Japan and America (Neven\&Siotis, 1996). All of the research achievement finds the relationship between FDI and R\&D are positive. Furthermore, they believed that the motivation for this phenomenon is technology innovation. In the year of 1996, Japanese MNEC improved their FDI about American semiconductor product. Almedia stated that their investment mainly focuses on purchasing technology patents (Almedia, 1996). Furthermore, there was a lot of foreign investment put into Silicon Valley. The aim of that is relying on this information channels to develop their technology. Moreover, technology can be a commodity to make significant profits in international business activities. In 1992, UNCTAD stated that the fee for technology transfer and license between parent company and subsidiaries is taking $80 \%$ in the international technology trade. The trend is going to be more frequently with the development of the global economy. In the year of 2005 , the income about technology transfer of IBM is $22.5 \%$.

Secondly, technology is also an essential motivation for developing countries' foreign investment operated in developed countries. Technology-oriented foreign investment in developing countries is mainly including technological M\&A and learning by doing (Karadjova and Dičevska, 2014). Technological M\&A is using crossborder $M$ method to acquire advanced technology and excellent R\&D team. If the company is limited by financial support to operate this strategy, learning by doing has always become an alternative strategy to develop its business. However, this method is always treated as illegal behaviours. Right now, the current legal behaviours in this business plan to improve technology are contracting advanced company's product manufacturing to get limited but adequate technical support. In the year of 2010, Geely Holding Group used cross-border mergers to have Volvo's assets from Ford Motor Company. Volvo company master advanced technology of automobile manufacturing and production. Their advantage is the disadvantage of Geely Holding Group. After that, Geely Holding Group master excellent R\&D team in American and advanced technology compared with other Chinese automobile manufacturing companies. Furthermore, Geely Holding Group had enough abilities to share Chinese high-end car market profits.

Technology is a critical factor for a company running in the global market. With the development of global business, there are more and more customers willing to spending their money on high-quality products. Whether advanced technology company use their technology to make profits or the developing countries' company use cross-border mergers to get advanced technology, both of them shows the strong relationship between technology and foreign R\&D strategies. In fact, technology is an important motivation of company to operate their investment in the other countries. It will reduce their R\&D cost and improve their competitiveness advantages in a short time in the local market. 


\subsection{INDUSTRY CLUSTERS}

There are some companies which are not limited by the single factor or all of the influenced factors for them are balance. When they operate their R\&D work into foreign countries, industry clusters always influence their make decision about entry strategy. In fact, industry cluster is the geographical group which use local resources and necessary industrial facilities to develop their business advantages. In fact, industry cluster will help enterprises reduces the cost of establishment and share regional competitiveness advantages such as transport, local policies and market explore. Furthermore, industry cluster will also help enterprises achieving information sharing to reduce their R\&D cost (Porter, 1990).

Silicon Valley is famous for its high-tech industry group worldwide. There is a lot of international company to establish an excellent R\&D team in there. To improve the company's technology innovation, Alcatel Company acquired Timetra in Silicon Valley. After 2006, Ericsson acquired Redback Networks Limited in Silicon Valle to achieve the same target with Alcatel. In the year of 2015, Chinese JD Group creates its Silicon Valley Research Center in Silicon Valley to address the issue about the Chinese market. In fact, all of those international company in favour of Silicon Valley's high-tech industry clusters. The employment within the cluster region also has a higher concentration; workforce specialization occurs through cluster formation. Due to this reason, companies would be more willing to enter into the industry clusters abroad to obtain workforce benefits. Furthermore, cooperative research was made more available within industry clusters, thus providing companies within the region a higher potential $R \& D$ development. Furthermore, the increase in density of competitor within the small area could increase competitive striving, and this pushes new R\&D development of the companies within it.

Industry clusters will help enterprises to reduce the cost of the establishment. The positive information sharing environment will also contribute to the enterprises' R\&D strategy. Right now, there are more, and more MNES operate their entry strategy to consider the advantage of industry clusters.

\section{THE RESEARCH ABOUT MAIN CHALLENGES OF R\&D}

\subsection{CULURAL CONFLICTS}

Culture is related to a process which uses behaviours to influence others achieving the same target in the social activities. In the year of 1983, Hofstede based on the IBM companies to research the imbalance among different people. He pointed out that there are strong relationships between national culture and staffs' attitude and behaviours. With the development of global business, there are a lot of cultural conflicts that happened in enterprises' M\&A. The challenges of regional enterprises' mergers and acquisitions are the imbalance among different enterprises' internal culture. The cultural conflicts of cross-border mergers and acquisitions are coming from the national culture and corporate culture. In fact, if the management cannot understand the national culture and their staff's habit, it will take negative influence on their control on a daily basis. In the negotiation of cross-border mergers and acquisitions, the imbalance among different national cultures will become a pivotal factor to influence the final achievement in the end.

Ssangyong Motor Company was a famous company in South Korea. Their target market is the national middle and high-level market. However, because of various reason, Ssangyong Motor Company had to face an embarrassing environment which they master advanced technology about motor manufacturing and great market share in the South Korea but their company cannot run in the South Korea (Newswires, 2016). Actually, there is an intense patriotism when South Korean customer purchases their motor. That create a barrier which limits the development of the foreign motor company in the South Korea. SAIC wants to use M\&A strategy to master advanced technology and the South Korean market share. Because of that, SAIC used more than 500 million dollars to purchase Ssangyong Motor Company's 48.9\% stock. However, this business strategy created negative influenced in the end. Most of South Korean believed that SAIC' aim is getting advanced technology. They think SAIC would not increasing investment in the scheduled time. Furthermore, the adjustment of Ssangyong Motor Company creates more negative influence in the South Korean market. Finally, SAIC had to give up this strategy in 2006. SAIC lost 700 million dollars for this business strategy.

Operating business plan in a foreign market is influenced by various factors. However, culture is a key factor to perform successfully. With the development of global business, there are more and more people starting to have nationalism and patriotism. It helps the development of local enterprises but creates limit the development of other foreign companies' growth. However, this problem of cultural conflict could be resolved to some extent by management restructuring and reorganization. This serves as a way for the parent company and subsidiary to unify the global team and align all of its aims and business structure.

\subsection{GOVERNMENT POLICES\&LAWS}

To protect national enterprises development, some countries use Green Barriers to Trade to limit other foreign companies' growth (Gokcekus et al., 2012). Those government policies were also taking negative influence on foreign countries, establishing R\&D presence in the local market. Furthermore, some developing countries' following "learning by doing" strategy to make up the imbalance of other company that master advanced technology (Bond and Ma, 2013). However, when their product put into the international market, their product often is banned export because of intellectual property issues. In the end, by influenced by some political factors, the foreign company establishing their $R \& D$ presence cannot be equal as local enterprises in the business environment. 
Coca-Cola Company is lacking juice market in the Chinese market. There are two important reasons. One is lacking technology. The other factor is lacking famous brand. In the year of 2008, Coca-Cola Company signed a purchase agreement with Chinese Huiyuan Company. However, this business agreement is banned by the Chinese Ministry of Commerce. Chinese government believe that this business strategy will take a negative influence on Chinese national brand protection (Financial Times, 2016). In the end, Coca-Cola Company had to give up this business plan. Right now, Coca-Cola Company's juice market sink into an unfavourable situation in the Chinese market.

The influence of local government policies on foreign companies establishing R\&D companies is obviously. Green Barriers to Trade always make a barrier to other countries establish R\&D presence. Furthermore, other laws problem, such as intellectual property issues and religious issues, are also becoming a challenge.

These legislation problems could be abolished through lawsuits to a higher government. In an example, the Volkswagen law in Germany was abolished in 2009 by the European central court of justice to allow Porsche to go on with its accusation. However, the case of appeal could put the parent company in a high-pressure environment, and the chances of a successful bid are low.

\subsection{MANAGEMENT ISSUES}

The company's internal management issues are always becoming challenges of the foreign company to establish R\&D presence. There are two critical problems in international company management. First of all, leadership behaviour is an essential problem in the company's internal control. Secondly, the autonomy of the R\&D subsidiary is another problem.

Traditional leadership theories address the authority of the leader and staff's work effectiveness. However, transformational leadership pointed out that the leader is supposed to take care of their followers' development (Carmeli, Atwater and Levi, 2010). Actually, it is difficult to find a suitable leader in the establishing process. With various reasons, Google Company had to give up the Chinese market in 2010. One of the important factors is Kaifu Li leaving, who was CEO of Google Chinese (Businessweek.com, 2016). Furthermore, the autonomy of the R\&D subsidiary will also make a challenge for their parent company. With the development of foreign market and technology sharing, R\&D subsidiary always enjoys enough autonomy. In fact, parent company' control abilities are reducing of their subsidiaries with the development of target market income and the reduction of imbalance about technology between subsidiaries and home companies. Philips Company has a lot of subsidiaries around the worldwide. However, Philips Company is starting to lose the control abilities of their subsidiaries (Bartlett and Ghoshal, 1995). Some subsidiaries research and develop new technology without Philips's agreement. When this research and development is failed, the cost will be paid by the Philips company.

With the reduction about control abilities of subsidiaries and cannot finding the right leader, establishing R\&D presence in foreign countries always have various problems. However, those issues still happened in the company running term and difficult to address on in the short time (Bartlett and Ghoshal, 1995). Because of that, the company's international management issue is another challenge for operating R\&D strategy in foreign countries.

\section{THE ANALYZE OF ENTREPRENEURIAL SUBSIDIARY BETWEEN CHINESE AND American}

The financial structure data is obtained from the financial report of the respective companies: Alto Electronics Co., Ltd., LDK Solar CO., Ltd and 3M Company, when the most recent year data is obtained. The macroeconomic data are obtained from the respective regulatory bodies or the national statistical department.

Table 1: The statistics of commercial bank loan to Chinese SMES between 2012 and 2016

\begin{tabular}{|l|l|l|}
\hline Year & Quarter & $\begin{array}{l}\text { The bank loan of Commercial } \\
\text { Bank to Chinese SMES } \\
\text { (Unit: 100,million) }\end{array}$ \\
\hline \multirow{4}{*}{2015} & Q1 & 23459.8 \\
\cline { 2 - 3 } & Q2 & 22542.7 \\
\cline { 2 - 3 } & Q3 & 22049.3 \\
\cline { 2 - 3 } & Q4 & 21413.2 \\
\hline 2016 & Q1 & 24950.9 \\
\cline { 2 - 3 } & Q2 & 24296.2 \\
\hline
\end{tabular}

(source from: China banking regulatory commission, 2016) 


\section{The statistics of NYSE Group Volume in All Stocks \\ Trades between 2012 and 2016 \\ (Unit: billions)}

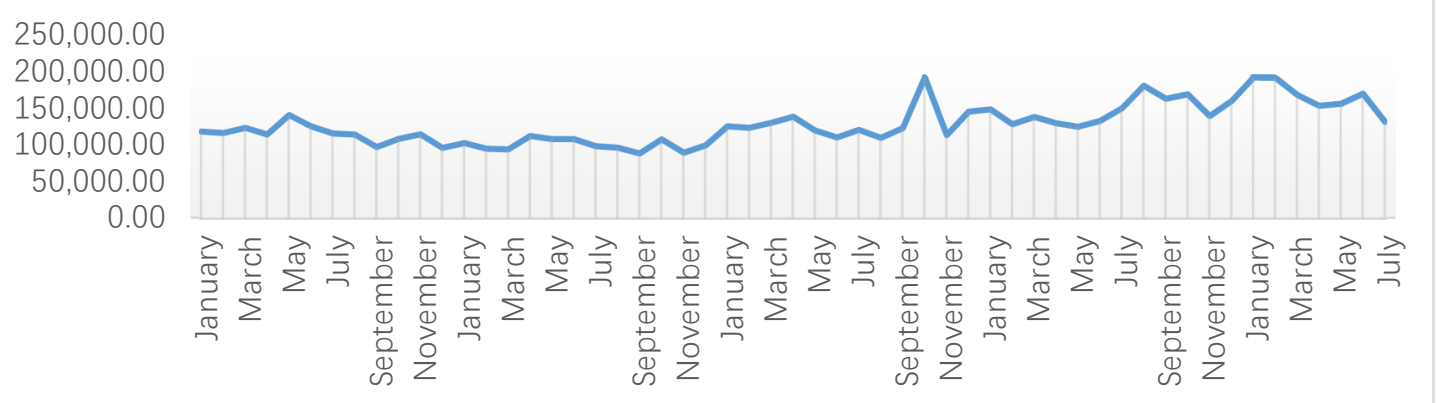

Figure 1: The statistics of NYSE Group Volume in All Stocks trades between 2012 and 2016

(Source from: NYSE, 2016)

In this research process, there are three Born Global Firms to choose. That includes Alto Electronic, Solar LDK and 3M company. Among them, Alto Electronic is a Chinese Born Global firms. It is existing in the bankbased financial system. Furthermore, Solar LDK is a company which belongs to Chinese company; however, it is attempting to finance in American stock market. It is a sample related to the bank-based financial system but market-oriented. In the end, $3 \mathrm{M}$ company is an American company. Different with other two, it is existing in the market-based financial system.

The debt to asset ratio of Alto Electronic company and 3 M company is almost steady between 2012 and 2015. However, LDK Solar CO., Ltd was going to increase in those past few years. Furthermore, $3 \mathrm{M}$ company keeps steady income growth in those years compared with the other two.Alto Electronic company's net income growth are significant fluctuation. Start 2011, LDK Solar CO., Ltd starts to financial loss. The continue equity financing and bank financing improve their debt asset ratio in the next few years. The more details are reflected by those following tables.

Table 2: The statistics of Alto Electronic Company

\begin{tabular}{|l|l|l|l|l|}
\hline \multicolumn{5}{|l|}{ Alto Electronic Company } \\
\hline Item & 2012 & 2013 & 2014 & 2015 \\
\hline $\begin{array}{l}\text { Total } \\
\text { assets }\end{array}$ & 6184885 & 6711483 & 7597149 & 7002600 \\
\hline $\begin{array}{l}\text { Total } \\
\text { Liabil } \\
\text { ities }\end{array}$ & 1133836 & 109.68 & 66.4 & 48.89 \\
\hline $\begin{array}{l}\text { Debt } \\
\text { Asset } \\
\text { ratio }\end{array}$ & $18 \%$ & 67.05 & 33.61 & 34.21 \\
\hline $\begin{array}{l}\text { Net } \\
\text { Incom }\end{array}$ & 7.95 & $16.29 \%$ & $19.81 \%$ & $17.40 \%$ \\
e & & & & \\
\hline
\end{tabular}

(source from: Alto Electronic, 2016)
Table 3: The statistics of LDK Solar CO., Ltd.

\begin{tabular}{|c|c|c|c|c|}
\hline \multicolumn{5}{|c|}{ LDK Solar CO., Ltd. } \\
\hline Item & 2011 & 2012 & 2013 & 2014 \\
\hline $\begin{array}{l}\text { Total } \\
\text { assets }\end{array}$ & $\begin{array}{l}6,853,8 \\
61\end{array}$ & $\begin{array}{l}5,024,2 \\
14\end{array}$ & $\begin{array}{l}3,047,0 \\
99\end{array}$ & $\begin{array}{l}2,954,9 \\
63\end{array}$ \\
\hline $\begin{array}{l}\text { Total } \\
\text { Liabiliti } \\
\text { es }\end{array}$ & $\begin{array}{l}6,009,2 \\
43\end{array}$ & $\begin{array}{l}5,203,6 \\
84\end{array}$ & $\begin{array}{l}5,149,4 \\
80\end{array}$ & $\begin{array}{l}5,267,3 \\
30\end{array}$ \\
\hline $\begin{array}{l}\text { Debt } \\
\text { Asset } \\
\text { ratio } \\
\end{array}$ & $88 \%$ & $104 \%$ & $169 \%$ & $178 \%$ \\
\hline $\begin{array}{l}\text { Net } \\
\text { Income }\end{array}$ & $\begin{array}{l}- \\
608,954\end{array}$ & $\begin{array}{l}- \\
1,052,0 \\
59\end{array}$ & $\begin{array}{l}- \\
1,637,2 \\
11\end{array}$ & $\begin{array}{l}- \\
269,684\end{array}$ \\
\hline
\end{tabular}

(Source from: LDK, 2016)

Table 4: The statistics of 3M Company

\begin{tabular}{|l|l|l|l|l|}
\hline 3M Company & \multicolumn{4}{l|}{ unit: Million } \\
\hline Item & 2012 & 2013 & 2014 & 2015 \\
\hline Total assets & 33841 & 33304 & 31209 & 32718 \\
\hline $\begin{array}{l}\text { Total } \\
\text { Liabilities }\end{array}$ & 15836 & 15602 & 18067 & 20971 \\
\hline $\begin{array}{l}\text { Debt Asset } \\
\text { ratio }\end{array}$ & $47 \%$ & $47 \%$ & $58 \%$ & $64 \%$ \\
\hline Net Income & 4444 & 4659 & 4956 & 4833 \\
\hline
\end{tabular}

(Source from: MMM, 2016)

\section{CONCLUSION}

In conclusion, pursuing a transnational strategy in changing business environment can help enterprises' master many advantages. However, it is difficult to operate by influenced by organizational structure and administrative heritage and strategies' characteristic. Furthermore, entrepreneurial subsidiary's characteristic refers to innovation, risk-taking, reactiveness, networking, learning and autonomy. As it is most likely for a company implementing the transnational strategy to possess 
entrepreneurial subsidiaries based on the four cases discussed, the benefits of having them are shown in terms of innovative output and performance to the firm itself as well as in terms of economic development for the local economy. There are various motivations and challenges of establishing R\&D presence in foreign countries. Based on the research of influencing company establishment factor, the main motivations of those companies include cheap labour cost, natural resources, and technology. Furthermore, relying on industry clusters to master regional competitiveness advantages is another important motivation. However, when the company operates its R\&D strategy in foreign countries, they have to face challenges such as cultural conflicts, local government policies, laws, and the company's internal management issues. Actually, company internal management issues are related to leadership behaviours and autonomy of R\&D subsidiaries.

\section{References}

1. Baranenko, (2014). USE OF ENVIRONMENTAL APPROACH TO INNOVATION-ORIENTED DEVELOPMENT OF INDUSTRIAL ENTERPRISES. American Journal of Applied Sciences, 11(2), pp.189-194.

2. Bond, E. and Ma, Y. (2013). Learning by Doing and Fragmentation. Pacific Economic Review, 18(5), pp.603-627.

3. Bartlett, C. and Ghoshal, S. (1995). Transnational management. Chicago: Irwin

4. Cai, F. (2010). Demographic transition, demographic dividend, and Lewis turning point in China. China Economic Journal, 3(2), pp.107-119.

5. Carmeli, A., Atwater, L. and Levi, A. (2010). How leadership enhances employees' knowledge sharing: the intervening roles of relational and organizational identification. J Technol Transf, 36(3), pp.257-274.

6. Dimitratos, P., Buck, T., Fletcher, M. and Li, N. (2016). The motivation of international entrepreneurship: The case of Chinese transnational entrepreneurs. International Business Review.

7. Expecting Silicon Valley, Finding Silicon Planar. (2014). Synfacts, 10(12), pp.1267-1267.

8. Financial Times. (2016). China blocks Coca-Cola bid for Huiyuan - FT.com. [online] Available at: http://www.ft.com/cms/s/0/5c645830-1391-11de9e32-0000779fd2ac.html\#axzz44POAxNBZ [Accessed 30 Mar. 2016].

9. Gassmann, O. and Han, Z., 2004. Motivations and barriers of foreign $R \& D$ activeities in China. $R \& D$ Management, 34(4), pp.423-437.

10. Gokcekus, O., Henson, J., Nottebaum, D. and John, A. (2012). Impediments to trade across the Green Line in Cyprus: Classic barriers and mistrust. Journal of Peace Research, 49(6), pp.863-872.

11. Ilo.org. (2015). Decent work in global supply chains. [online] Available http://www.ilo.org/actrav/info/international-journal-
labour-research/WCMS_433853/lang--en/index.htm [Accessed 30 Mar. 2016].

12. Newswires, S. (2016). SAIC of China to Take ControlOf Korean Ssangyong Motor. [online] WSJ. Available at: http://www.wsj.com/articles/SB1098992568972587 68 [Accessed 30 Mar. 2016].

13. Kumar, N., 2001. Determinants of location of overseas R\&D activity of multinational enterprises: the case of US and Japanese corporations. Research Policy, 30(1), pp.159-174.

14. Karadjova, V. and Dičevska, S. (2014). Investment Activity in Small Open Economies. TI, 05(02), pp.65-78.

15. Rogers, R. (2009). An economic history of the American steel industry. London: Routledge.

16. Tann, J. (2015). Borrowing Brilliance: Technology Transfer Across Sectors in the Early Industrial Revolution. The International Journal for the History of Engineering \& Technology, 85(1), pp.94-114.

17. Hoppe, M., 1993. The effects of national culture on the theory and practice of managing $R \& D$ professionals abroad. R \& D Management, 23(4), pp.313-325.

18. Usa.arcelormittal.com. (2016). ArcelorMittal - Our history. [online] Available at: http://usa.arcelormittal.com/Who-we-are/Ourhistory/ [Accessed 28 Mar. 2016].

19. Yang, Y. and Ma, M. (2013). Proceedings of the 2nd International Conference on Green Communications and Networks 2012 (GCN 2012). Berlin: Springer. 